\title{
ANALYTICAL STUDY OF DIABETIC FOOT INFECTIONS AND OTHER SSTIS
}

\author{
Chandu Sambasivudu1, Chandu Vineela², K. P. K. N. Venkata Ramana ${ }^{3}$
}

${ }^{1}$ Consultant General Surgeon, Department of General Surgery, NRI Medical College, Guntur, Andhra Pradesh, India.

${ }^{2}$ Consultant Physician, Department of General Medicine, Sri Venkateswara Nursing Home, Tenali, Andhra Pradesh, India.

${ }^{3}$ Consultant Paediatrician, Department of Paediatrics, Sri Venkateswara Nursing Home, Tenali, Andhra Pradesh, India.

ABSTRACT
BACKGROUND
In the modern era, diabetes is the most common metabolic disorder. Infections and mortality are 4.2 times higher in diabetics than
in non-diabetics.[1] Most commonly they are highly difficult to treat, especially of foot and other lower limb infections.
The objectives of this study are 1. to know the morbidity and mortality of diabetic infections of the foot and other SSTIs and
2. to estimate the amputation rates (both major and minor) of the lower limbs, in diabetic patients.

\section{MATERIALS AND METHODS}

We have studied retrospectively 290 cases of diabetic infections of lower limb and other areas operated by single surgeon [1 1 st Author] for the last 10 years. We have classified and analysed in the following order-

1. The site of lesion.

2. Severity of the lesion and part involved.

3. Associated complications if any.

4. Mode of surgical treatment.

5. Outcome- morbidity and mortality.

The surgical management is classified into surgery done in $100 \%$ of patients-

1. Simple incisions and debridement- $81.35 \%$

2. Tendon and muscle excisions $-12.4 \%$

3. Amputations, both major and minor- $17.2 \%$

4. Vascular (ischaemic) management- both conservative and reconstructive- $4.8 \%$

5. Management of septic shock- $4.8 \%$

6. Reconstructive and rehabilitative procedures like split skin grafts (13.1\%) and major amputations (2.7\%) are also studied.

\section{RESULTS}

Nearly, 95\% of patients recovered well. Among them, minor amputations like removal of the part of toe or whole toe or two toes includes 50 out of 290. Some of the patients presented with already amputated toe (in other hospitals) with non-healing wound. They are also included in the amputations category. Major amputations like below knee, above knee, knee disarticulation- $2.7 \%$. 5 $(1.7 \%)$ patients died due to septic shock (3), GI bleed (1) and MI (1). Nearly 9 patients (3.1\%) have left the hospital without completion of treatment for various reasons (LAMA)- $3.1 \%$.

\section{CONCLUSION}

The amputation rate, especially major amputation rate in diabetic foot is decreased considerably.

\section{KEY WORDS}

Diabetes, Ulcers, Cellulitis, Debridement, Necrotising Fasciitis, Amputations.

HOW TO CITE THIS ARTICLE: Sambasivudu C, Vineela C, Ramana KPKNV. Analytical study of diabetic foot infections and other SSTIS.J. Evolution Med. Dent. Sci. 2018;7(32):3604-3609, DOI: 10.14260/jemds/2018/809

\section{BACKGROUND}

Diabetes mellitus is the most common metabolic disorder. It is known in Indian and western medical literature for the last many centuries. The term diabetes is introduced in the medical literature by Aretaeus of Cappadocia (2) It is known as sweet urine disease. In 1682, Brunner identified connection between pancreatectomy and diabetes symptoms.[2]

'Financial or Other Competing Interest': None.

Submission 23-06-2018, Peer Review 20-07-2018,

Acceptance 26-07-2018, Published 06-08-2018.

Corresponding Author:

Dr. Chandu Sambasivudu

Consultant General Surgeon,

D. No. 22-7-20/1, Sri Venkateswara Nursing Home,

Kothapeta, Tenali-522201,

Guntur District, Andhra Pradesh, India.

E-mail: dr.ch.sivudu@gmail.com

DOI: $10.14260 /$ jemds $/ 2018 / 809$

\section{(c) $(\mathbf{P})$}

The incidence of diabetes is increasing. It has been rapidly increasing for the last three decades. It is around $0.2 \%-0.3 \%$ in 19 th century, around $4.7 \%$ in 1984 and approximately $10 \%$ in 21 ${ }^{\text {st }}$ century. ${ }^{[3-5]}$ As per The American Diabetic Federation, around 387 million people (8.3\%) were living with diabetes as off 2014.[6] As per the American Diabetic Association, 9.3\% of US population i.e. 29.1 million people are affected with diabetes.[7] According to World Journal of Diabetes published in February 2015, the number of patients with Diabetes mellitus are 30 million in 1985, 177 million in 2000 and 285 million in 2010.[8]

Accordingly, the infection rates of lower limbs in diabetic patients are increasing proportionately. Diabetic foot ulcer prevalence is estimated around $4-27 \%$ in diabetic population.[9,10,11,12,13] $20 \%$ of hospital admissions from diabetes mellitus patients are due to diabetic foot ulcer.[14] If we add other SSTIs of diabetic patients naturally, it will be higher. 
The High Prevalence of Infections, specifically in Lower Limbs are due to-

1. Neuropathy (both sensory and autonomic).

2. Biomechanics of foot. (Unopposed power of flexorspressure over bony prominences).

3. Peripheral vascular blocks (Microangiopathy as well as Macroangiopathy).

4. Hyperglycaemia (Uncontrolled).

5. Poor wound healing in diabetes.

6. Smoking and obesity.

Foot ulcers and SSTIs are 4.2 times more common in diabetics compared to non-diabetics.[1] 15\% diabetic patients will suffer with diabetic foot ulcer once in their lifetime and is difficult to get treated.[10] Life is endangered due to other severe infections like necrotising fasciitis, decubitus ulcer, carbuncles, septic shock and other related complications like cardiac and renal. Hence, we tried to analyse diabetic foot infection and other SSTIs.

\section{MATERIALS AND METHODS}

It is a descriptive study. 290 cases of infections of diabetic patients treated for the last 10 years are reviewed. To exclude variations in the management, both surgical and postoperative care cases done by single surgeon (1st author) in our own hospital are included in this study.

\section{RESULTS}

Analysis- As follows

\begin{tabular}{|c|c|}
\hline Males & Females \\
\hline $196 / 290(67.6 \%)$ & $94 / 290(32.4 \%)$ \\
\hline \multicolumn{2}{|c|}{ Table 1. Sex Wise Distribution } \\
\hline
\end{tabular}

Males are more commonly affected than females- $67.6 \%$ vs. $32.4 \%$.

Male people go outside either for farm work or outside work. Trauma incidence is more in males than females. Hence, incidence is more in males.

\begin{tabular}{|c|c|c|c|}
\hline Age & Males & Females & Total (\%) \\
\hline < 40 years & 6 & 10 & $16(5.55 \%)$ \\
\hline 41-50 years & 28 & 20 & $48(16.5 \%)$ \\
\hline 51-60 years & 70 & 34 & $104(35.9 \%)$ \\
\hline 61-70 years & 76 & 22 & $98(33.8 \%)$ \\
\hline 71-80 years & 16 & 8 & $24(8.3 \%)$ \\
\hline Total & 196 (67.6\%) & 94 (32.4\%) & $\mathbf{2 9 0 ( 1 0 0 \% )}$ \\
\hline \multicolumn{4}{|c|}{ Table 2. Age Wise Distribution } \\
\hline
\end{tabular}

In young age group i.e. less than 40 years more female patients are affected- $(10 / 290=3.4 \%)$ than male patients i.e. $(6 / 290=2 \%)$.

$6^{\text {th }}$ decade i.e. 51 - 60 years people are more commonly affected i.e. $104 / 90=35.9 \%$ followed by 7 th decade $67-70$ years- $98 / 290=33.8 \%$, both together $69.7 \%$. This is due to high incidence of diabetes with increasing age. It decreases in $8^{\text {th }}$ decade as lifespan comes down.

\section{Area of Involvement}

1. Foot- Plantar and dorsum- $232 / 290=80 \%$.

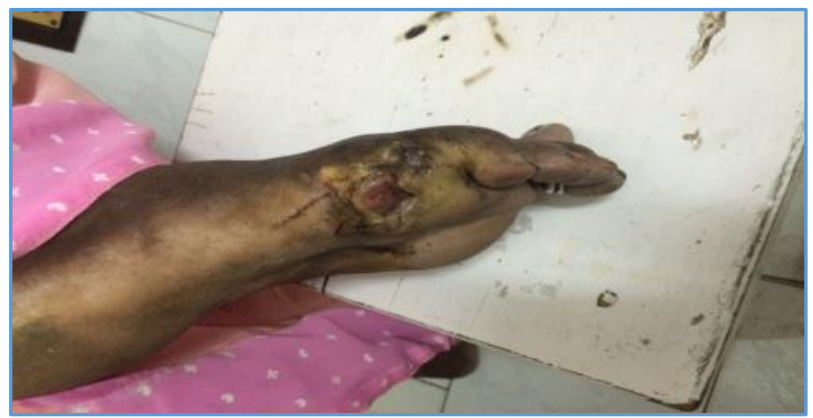

Figure 1. Neuropathic Ulcer

2. Side- Not much different.

3. Fournier's gangrene, decubitus ulcer and gluteal involvement- $30 / 290=10.3 \%$.

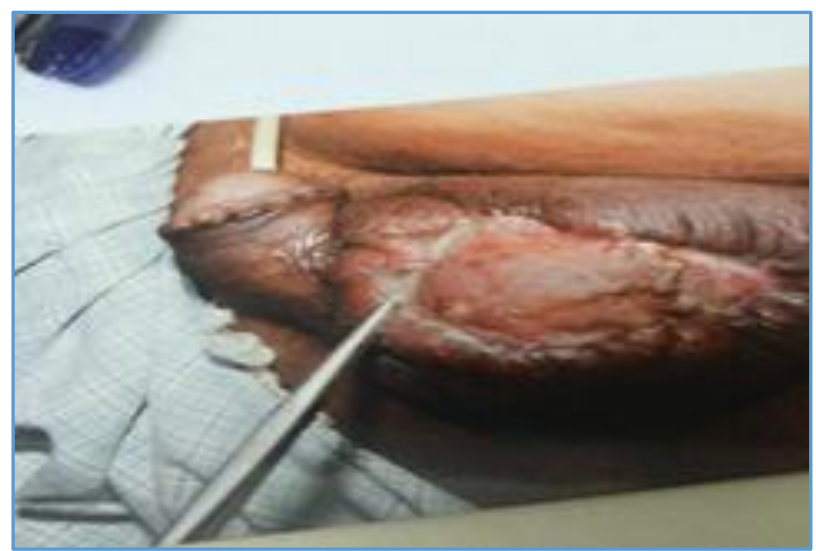

Figure 2. SSG following Fournier's Gangrene

4. Upper limb involvement (fingers + hand + arm)$14 / 290=4.8 \%$.

5. Carbuncles $-14 / 290=4.8 \%$.

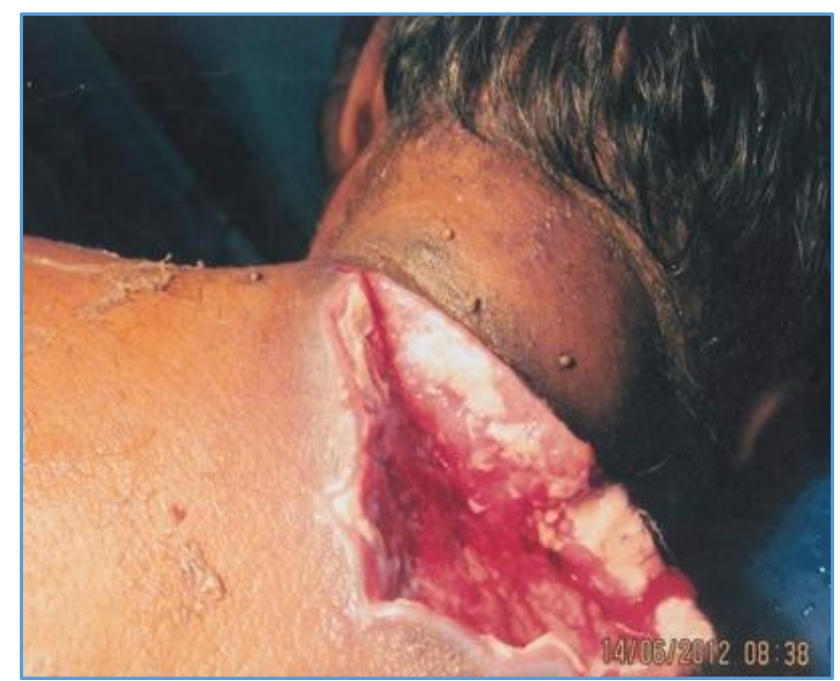

Figure 3. Healing Carbuncle over back of the Neck

As expected lower limb involvement i.e. sole, dorsum of the foot and leg is affected with infections in $80 \%$ of the people. In rest of the areas, only $20 \%$ of infection taken place. 


\section{Pathological Lesion Wise Involvement}

- Cellulitis (moderately severe) and necrotising fasciitis$67.6 \%$

- Vascular ischaemia- $4.8 \%$

- In general presentation with septic shock- $4.8 \%$

- Carbuncles- $4.8 \%$

- $\quad$ Diabetic foot ulcer simple + (grade I and grade II) + simple lesions of upper limb $22 \%$
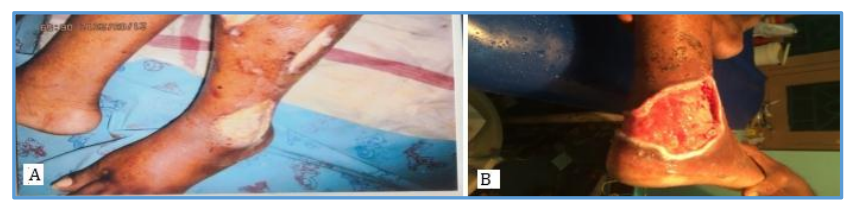

\section{Figure 4 (A and B). Healing Lower Limb Ulcers- Granulation Tissue Coming}

\section{Surgical Management}

- $\quad$ Surgery done in $100 \%$ of patients.

- Incisions and debridement- $236 / 290=81.35 \%$

- Excision of tendons and muscles- $36 / 290=12.4 \%$

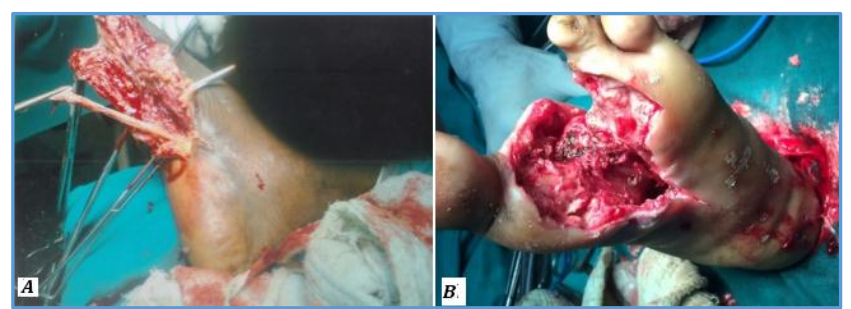

Figure 5 (A and B). Excision of Tendon and Disarticulation of Toes

- $\quad$ Minor amputation and disarticulations- 50/290=17.2\% - $(50 / 232=21.5 \%)$.

- Offloading- $12 / 290=4.1 \%-(12 / 232=5.1 \%)$.

- $\quad$ Major amputations- $8 / 290=2.7 \%-(8 / 232=3.4 \%)$.

- Major amputations include below knee, above knee, knee disarticulations, all together $8 / 290=2.7 \%$.

- $\quad$ Split skin grafts- $38 / 290=13.1 \%$.

- Simple cellulitis- incisions- healed with secondary intention.

- $\quad$ SSG (skin grafts) needed where large areas of skin are lost due to gangrene.

- Major amputations are due to severe ischaemia 6 cases and necrotising fasciitis 2 cases.

Approximately, 95\% of patients recovered well. Out of them, minor amputations like removal of the part of toe or whole toe or two toes includes 50 out of 290. Some of the patients are presented with already amputated toe elsewhere with non-healing wound. They are also included in the amputations category. Major amputations like below knee, above knee, knee disarticulation- 2.7\%; 5 (1.7\%) patients died due to septic shock (3), GI bleed (1) and MI (1). Nearly, 9 patients $(3.1 \%)$ had left the hospital without completion of treatment for various reasons (LAMA)- 3.1\%.

\section{DISCUSSION}

The Diabetic incidence has increased in recent 3 decades enormously in our region due to the lifestyle changes in this part of Andhra Pradesh also. The Diabetic incidence has increased to $10 \%$ or more. Infections are also increased in the diabetic population proportionately due to-

- Increased average lifespan of people.

- Increased duration of diabetic disease in persons.

- Associated increased vascular and neurological complications, diabetic ulcers, cellulitis and necrotising fasciitis are also gone up.

- Uncontrolled diabetes for long duration will also increase the complication rate.[15]

Due to the above reasons diabetic foot and other SST infections, admissions in hospitals has gone up. Nearly, 20\% of all diabetic admissions are diabetic foot infections.[14]

Diabetic foot infections lead to hospitalisation and thereby financial loss. Sometimes, loss of part of toe or toe or part of the foot/ foot/ part of limb, which will lead to disability to the person and loss of self-confidence and productivity loss.

If it is happening in the $4^{\text {th }}$ or $5^{\text {th }}$ decade, that is loss in productivity, which will affect the economical position of the society and thereby the nation also.

As My Hospital is located in semi-urban place in middle of Andhra Pradesh- Present capital area, most percentage of people are depending on the Agriculture Farming. Thereby acute infections might be more common than chronic infections. Second reason might be farming people get more injuries. Majority of them come directly to us, hence we are able to save majority of them. Mortality and LAMA are less than 5\% when compared to other studies of severe infections.[16] Interval between admission to the hospital and timing of surgery is less than hours might be the reason for low mortality, even though severe NSSTI is present.

\section{Bacteriology}

In the literature, majority of the diabetic infections are polymicrobial. Staphylococcus aureus is the predominantly found organism followed by Streptococcus pyogenes and anaerobic bacteria.[17] The same is true of my cases also. In longstanding cases, Pseudomonas aeruginosa is also present in some of the cases in my patients.

This also correlates with other studies from other areas of the world.[18]

Majority of the cases of my study are Wagner and Meggitt's classification III and IV. Moderate-to-severe infections involving the skin, soft tissues, tendons and part of the bone (around 60\%) and nearly $8-10 \%$ of the patients are Grade V of Wagner Meggitt (Severe cellulitis extending to knee and necrotising fasciitis- NSSI). Necrotising fasciitis spreads by leaps and bounds hour by hour mimicking/similar to gas gangrene.[19] The discolouration of skin followed by blackening of the skin advancing upwards and circumferentially with patchy areas. These are all acute infections with rapidly progressing cellulitis with above symptoms presented with shock, systolic BP ranging from 40 - $80 \mathrm{mmHg}$. On opening, foul-smelling pus, dish water like Greyish exudates with rapidly progressing involving skin, subcutaneous tissues, muscles and tendons. During surgery the pathology is invariably much greater and more extensive than visible clinically. [20-22] It is just like iceberg phenomenon. 
These patients always invariably have oliguria, anuria with elevated blood urea nitrogen and serum creatinine levels. In these cases, we treat actively both by medical and surgical management simultaneously.

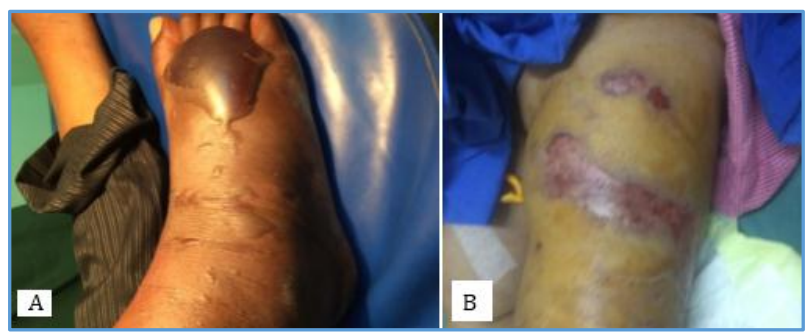

Figure 6 ( $A$ and B). Necrotising Fasciitis Foot and Lower Limb

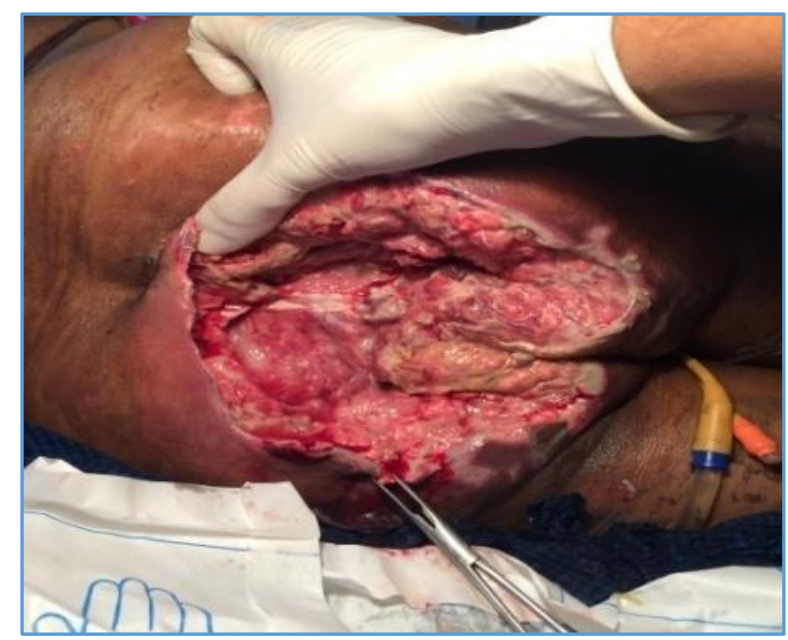

Figure 7. Large Decubitus Ulcer-Healing

Medical management includes treatment of shock, treatment of sepsis with IV fluids, antibiotics and inotropes and rapid acting soluble human insulins and by IV diuretics once blood pressure is stabilised. We take extra care in renal function and urine output is maintained hourly. Antibiotics are started empirically in the beginning. Later switched over to culture sensitivity antibiotic combinations.

Steroids and Inotropes-like Dopamine or Dobutamine at the dose of 3 - 20 micrograms/ kg/ min are given depending upon the requirement for 2 - 10 days' duration in my experience. Emergency surgery is done with or without anaesthesia, either bedside or in operation theatre.[22-25] Patients with severe shock, we operated at bedside without anaesthesia. They carry higher mortality rate with anaesthesia also. We have operated under ankle block or spinal anaesthesia. General anaesthesia is used sparingly. Excision of all dead tissues including skin subcutaneous tissue, muscles, tendons, phalanges or toes were done till viable bleeding tissue comes. In spite of surgical debridement and medical management, some of them progresses. They need multiple debridements during dressings daily or twice a day. Advanced dressing methods are used with application of local antibiotics (Injectables/ Powder) and application of anti-infective solutions- povidone + iodine, and tissue regenerators and growth factors. Most of the deaths are due to multiorgan failure. Among the less severe infection cases, we manage by single-to-multiple liberal incisions + debridement of all dead tissues. Regular OD or BD dressings are done till the healthy granulation tissue comes.
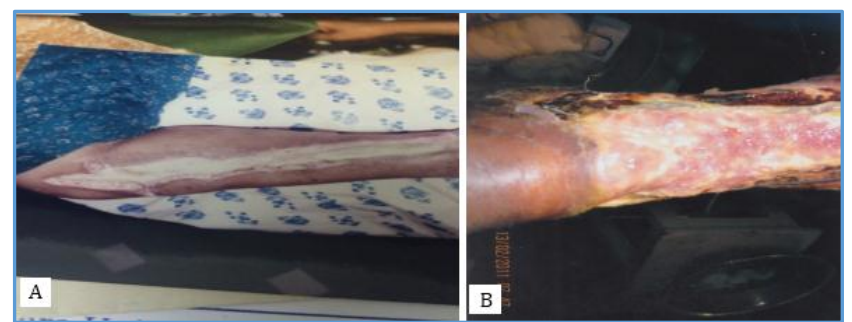

\section{Figure 8 (A and B). Long Incisions for Cellulitis and Gangrene}

We have resorted to amputations in (1) Osteoarticular sepsis or as a life-saving measure in some patients (guillotine method).[3] $18 \%-20 \%$ of the minor and major amputations are done in my series, which is comparable to the literature published in Harrison's text book of internal medicine which has quoted to $14 \%-24 \%$.[26] Offloading is good in chronic ulcers of mild ischaemic and neuropathic aetiology, which gave good results.

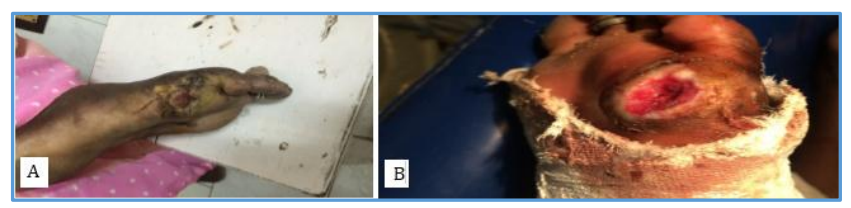

Figure 9 (A and B). Healing changes in Neuropathic Ulcer Foot after Offloading

Mainly debridement + offloading method is used in mildto-moderate infections (Grade I and Grade II of Wagner's classification) which gave good results.[27-28] Major vascular blocks which needed vascular grafts are not included in my study.

\section{VAC Therapy}

Negative pressure suction therapy is useful in clean wounds, which will facilitate rapid healing in many studies. But majority of my cases are necrotic and gangrenous, spreading cellulitis. Moreover, it is a costly treatment. Hence, I have not used this mode of treatment.[29-30]

\section{Hyperbaric 0xygen Therapy}

Doubtful results in different studies. Hence, I have not tried this modality.[31]

In olden days and middle part of $20^{\text {th }}$ century amputation like $\mathrm{BK}, \mathrm{AK}$, Knee disarticulations are done more commonly (Nearly $25 \%$ to $30 \%$ ). But now they are reduced to minor amputations of toe or couple of toes. Most of the patients needed long duration of hospital stay from 5 - 70 days due to necrosis/ gangrene of the subcutaneous tissue facia and tendons, which needed multiple debridements plus dressings till complete coverage of granulation tissue comes and later application of skin grafts.

In our experience, daily dressings with removal of the necrotic/ gangrenous dead tissue whenever appeared is the 
key factor to control the infection. Application of sometimes local antibiotic solutions in resistant cases and use of local injectable antibiotics into borders of the infected tissue. Tissue regenerators and stimulators like placenta derived products Placentrex and platelet derived growth factors (PDGF- plermin - human recombinant - PDGF) are much useful and gave good results in my cases. [32-35]

\section{Reconstruction and Rehabilitation Surgeries}

Application of skin grafts is 38 cases (13.1\%) out of 290 cases is higher in our series, because of high limb salvage rate. We could not get exact $\%$ of reconstructive grafts rate in other series.

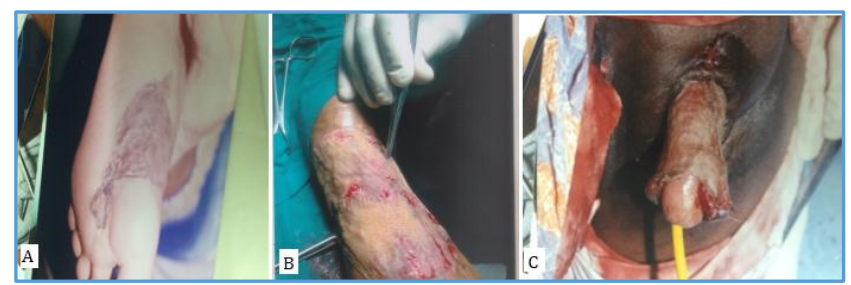

Figure 10 (A, B and C). Application of SSG in Foot and Penis

\section{CONCLUSION}

With our target in treating the diabetic foot and SSTIs is- To save the life of patient.[2] To prevent amputations, mainly major thereby decreasing the disability and decreasing the cost of treatment with early and vigorous surgical management, i.e. operating as early as possible from the time of admission to the hospital and surgical debridement, simultaneously tackling medical problems- will lead to better prognosis. Following this principle, we are able to decrease mortality

to

$2 \%-5 \%$ (including LAMA deaths) in spite of multiorgan involvement in many of the cases. Some of the LAMA cases died at home. $2.7 \%$.

We are able to decrease the major amputations to nearly

Long hospital stay is due to severe necrotising fasciitis with loss of large areas of skin, which needed long duration for granulation tissue to develop, followed by skin grafting in the same admission.

\section{REFERENCES}

[1] Acott AA, Theus SA, Kim LT. Long-term glucose control and risk of perioperative complications. Am J Surg 2009;198(5):596-9.

[2] David C, Sabiston Jr. Davis-Christopher Text book of surgery. The biological basis of modern surgical practice. $11^{\text {th }}$ edn. Philadelphia, London, Toronto: WB Saunders Company 1978: p. 198.

[3] Murthy PD, Pullaiah B, Rao KV. Survey for detection of hyperglycemia and diabetes mellitus in Tenali. In: Bajaj JS, edr. Diabetes mellitus in developing countries. New Delhi: Interprint 1984: p. 55-60.

[4] Ramachandran A, Snehalatha C, Latha E, et al. Impact of urbanization on the lifestyle and on the prevalence of diabetes in native Asian Indian population. Diabetes Res Clin Pract 1999;44(3):207-13.

[5] Mohan V, Deepa M, Deepa R, et al. Secular trends in the prevalence of diabetes and impaired glucose tolerance in Urban South India--the Chennai Urban Rural
Epidemiology study (CURES-17). Diabetologia 2006;49(6):1175-8.

[6] International Diabetic Federation 2013.

[7] Centers for Disease Control Prevention. National Diabetes Statistics Report: estimates of diabetes and its burden in the United States, 2014. Atlanta, GA: US Department of Health and Human Services. 2014 (American diabetic statistics report and its burden in the United States).

[8] Shaw JE, Sicree RA, Zimmet PZ. Global estimates of the prevalence of diabetes for 2010 and 2030. Diabetes Res Clin Pract 2010;87(1):4-14.

[9] Cavanagh PR, Lipsky BA, Bradbury AW, et al. Treatment for diabetic foot ulcers. Lancet 2005;366(9498):1725-35.

[10] Leone S, Pascale R, Vitale M, et al. Epidemiology if diabetic foot. Infez Med 2012;(20 Suppl 1):S8-S13.

[11] Richard JL, Schuldiner S. Epidemiology of diabetic foot problems. Rev Med Interne 2008;(29 Suppl 2):S222S30.

[12] Nather A, Bee CS, Huak CY, et al. Epidemiology of diabetic foot problems and predictive factors for limb loss. J Diabetes Complications 2008;22(2):77-82.

[13] Bakri FG, Allan AH, Khader YS, et al. Prevalence of diabetic foot ulcer and its associated risk factors among diabetic patients in Jordan. Med J 2012;46(2):118-25.

[14] Snyder RJ, Hanft JR. Diabetic foot ulcers-effects on QOL, costs and mortality and the role of standard wound care and advanced-care therapies. Ostomy Wound Manage 2009;55(11):28-38.

[15] Kolagal M, Symons RG, Hirish IB, et al. Peri-operative hyperglycemia and risk of adverse events among patients with or without diabetics or non-diabetics. Annals of Surgery 2015;261(1):97-103.

[16] Doherty GM. Current diagnosis and treatment surgery. Vol. 1. New Delhi: McGraw-Hill Education (India) Private Limited., 2015: p. 95.

[17] Doherty GM. Causative agents' current diagnosis and treatment surgery. 14th edn. New Delhi: McGraw-Hill Education (India) Private Limited., 2015: p. 94.

[18] Eke N. Fournier's gangrene: a review of 1726 cases. $\mathrm{Br}$ J Surg 2000;87(6):718-28.

[19] McHenry CR, Brandt CP, Piotrowski JJ, et al. Idiopathic necrotizing fasciitis: recognition, incidence and outcome of therapy. Am Surg 1994;60(7):490-4.

[20] McHenry CR, Compton CN. Soft tissue infections. In: Malangoni MA, Soper NJ, eds. Problems in general surgery. Philadelphia: Lippincott Williams and Wilkins 2002: p. 7.

[21] Anaya DA, Dellinger EP. Necrotizing soft-tissue infection: diagnosis and management. Clinical Infect Dis 2007;44(5):705-10.

[22] McHenry CR, Piotrowski JJ, Petrinic D, et al. Determinants of mortality for necrotizing soft-tissue infections. Ann Surg 1995;221(5):558-65.

[23] Anaya DA, McMahon K, Nathens AB, et al. Predictors of mortality and limb loss in necrotizing soft-tissue infections. Arch Surg 2005;140(2):151-8. 
[24] Rouse TM, Malangoni MA, Schulte WJ. Necrotizing fasciitis: a preventable disaster. Surgery 1982;92(4):765-70.

[25] Elliott DC, Kufera JA, Myers RA. Necrotizing soft tissue infections. Risk factors for mortality and strategies for management. Ann Surg 1996;224(5):672-83.

[26] Longo DL, Kasper DL, Hauser SL, et al. Harrison's principles of internal medicine. Vol. 2. 18 th edn. New York, Chicago, McGraw-Hill Medical 2012: p. 2987.

[27] http://ndep.nih.gov/publications/Publication Details.aspx? PubId=116. Accessed 12 February 2013.

[28] Pinzur MS, Solvenkai MP, Trepman E. Guidelines for diabetic foot care. The Diabetes Committee of the American Orthopaedic Foot and Ankle Society. Foot Ankle Int 1999;20(11):695-702.

[29] Vikatmaa P, Juutilainen $V$, Kuukasjärvi $P$, et al. Negative pressure wound therapy: a systematic review on effectiveness and safety. Eur J Vasc Endovasc Surg 2008;36(4):438-48.

[30] Ubbink DT, Westerbos SJ, Nelson EA, et al. A systematic review of topical negative pressure therapy for acute and chronic wounds. $\mathrm{Br}$ J Surg 2008;95(6):685-92.
[31] O’Reilly D, Pasricha A, Campbell K, et al. Hyperbaric oxygen therapy for diabetic ulcers: systematic review and meta-analysis. Int J Technol Assess Health Care 2013;29(3):269-81.

[32] Bennett SP, Griffiths GD, Schor AM, et al. Growth factors in the treatment of diabetic foot ulcers. $\mathrm{Br} \mathrm{J}$ Surg 2003;90(2):133-46.

[33] Wieman TJ. Clinical efficacy of becaplermin (rhPDGFBB) gel. Becaplermin Gel Studies Group. Am J Surg 1998;176(2A Suppl):S74-S9.

[34] Knighton DR, Ciresi KF, Fiegel VD, et al. Classification and treatment of chronic nonhealing wounds. Successful treatment with autologous platelet-derived wound healing factors (PDWHF). Ann Surg 1986;204(3):322-30.

[35] Steed DL. Clinical evaluation of recombinant human platelet-derived growth factor for the treatment of lower extremity ulcers. Plast Reconstr Surg 2006;117(Suppl 7):S143-S9, discussion S150S51. 